IRENEUSZ KOEPKE

Instytut Filozofii UMK

\title{
Szubienica na Krakowskim Przedmieściu, czyli o historii „paluchem pisanej”
}

„więc tak, będzie wisiał, Na wietrze i na deszczu będzie się kołysał, Bez pogrzebu i onej ostatniej posługi, Będzie wiatrom bezecne igrzysko czas długi"*

S E B A S T I A N F. K L O N O W I C Z

Sawę i uznanie można zdobyć na wiele sposobów. Jeden z najbardziej $\checkmark$ kontrowersyjnych, a co za tym idzie, interesujących komentatorów Hegla - Alexandre Kojève (Kożewnikow) zyskał sławę dzięki temu, że - jak pisze Vincent Descombes - posiadł rzadką odwagę „kompromitowania filozofii w sensie, w jakim się mówi o „kompromitujących znajomościach” - wskutek skierowania jej [tzn. filozofii - I. K.] ku rejonom istnienia, jakie dotychczas niechętnie nawiedzała: cynizmowi politycznemu, skuteczności masakry i przemocy oraz, w sposób ogólny, bezrozumnemu pochodzeniu tego, co rozumne. [...] Kojève przekazał swym słuchaczom terrorystyczną koncepcję dziejów"1. Warto, mając na uwadze powyższe słowa, podążyć w rejony wstydliwe, a przecież tak dla ludzi istotne. Dlatego też, niniejsza praca będzie po-

S. F. Klonowicz, Worek Judaszowy.

V. Descombes, To samo i inne. Czterdzieści pięć lat filozofii francuskiej (1933-1978), przeł. B. Banasiak, K. Matuszewski, Warszawa 1997, s. 21. 
święcona zagadnieniu przemocy, przy czym zaznaczmy od razu, że nie pretenduje ona do ujęcia tego obszernego i złożonego tematu w sposób całościowy. Chodzi raczej o zasygnalizowanie znaczenia przemocy w pewnych sferach ludzkiej aktywności, a nade wszystko w polityce.

Co jakiś czas na rynku wydawniczym pojawiają się w publikacje, które wywołują szeroki oddźwięk, zarówno w kręgach krytyki literackiej, jak i naukowej, społecznej czy politycznej. Niektóre z nich celowo zostały napisane, by wywołać taki efekt, inne zaś rozgłos zdobywają poprzez odpowiednią interpretację i zaadoptowanie. Niewiele powstało w ostatnich latach dzieł literackich, które byłyby tak szeroko komentowane jak książki Jarosława Marka Rymkiewicza. Dwie z nich są tutaj szczególne: Wieszanie i Kinderszenen, wydane odpowiednio w 2007 roku i w 2008 roku. Książki te, jak to zwykle bywa w tego typu przypadkach, wzbudziły skrajne emocje. Spierano się na łamach pism, w radiu, telewizji i w Internecie. W znakomitej większości przypadków krytycy i publicyści przywoływali te same cytaty. Swoje tezy podpierali identycznymi fragmentami książki. Nie chciałbym jednak tutaj podsumowywać tych dyskusji, gdyż przekraczałoby to znacząco rozmiary niniejszej pracy. Chciałbym się natomiast bliżej przyjrzeć książce Wieszanie, w której autor porusza tak istotne kwestie, jak: tożsamość narodowa, narodowa historiozofia, ale także skuteczność aktu przemocy w jego wymiarze katharsis. Inną istotną rzeczą, którą proponuje nam Rymkiewicz jest alternatywna wersja wydarzeń, a nawet - alternatywna Historia. Przy tej okazji warto zwrócić uwagę na fenomen przemocy jako swoistego „aktu założycielskiego”, co postaram się uczynić w dalszej części mojej pracy.

Istnieje kilka charakterystycznych fragmentów będących osią i wyznacznikami tez, jakie podsuwa nam Rymkiewicz. Względnie najważniejszy fragment jego książki, oddający jej przesłanie brzmi: „Czy gdyby Polacy w ostatnich dniach sierpnia 1794 roku powiesili pod kościołem Bernardynów (albo trochę dalej, na szerokim Krakowskim Przedmieściu, pod oknami królewskiego burdelu - kamienicy Sophie Lhullier) króla, który zdradził, dzieje insurekcji potoczyłyby się jakoś inaczej? Tego oczywiście wiedzieć nie możemy - wszystko to i tak mogło skończyć się Maciejowicami oraz rzezią Pragi. Ale można było zaryzykować - i trzeba powiedzieć, że przywódcy insurekcji, Kościuszko, także Ignacy Potocki i Hugo Kołłątaj, także dwaj generałowie, Jakub Jasiński i Józef Zajączek, przegapili wtedy tę niezwykłą chwilę, jedną z tych chwil, które w dziejach narodów pojawiają się niezwykle rzadko; tę chwilę, w której przed Polakami otwierała się jakaś zupełnie inna przyszłość (niż ta, która nastąpiła) - przyszłość królobójców. Polacy mogli stać się wtedy innym narodem, ich dzieje można było wtedy skierować w inną stronę, mogły też same (popchnięte utajona w nich dziką, wulkaniczną si- 
łą) skierować się w inną stronę - niewyobrażalną i piękną jak wszystko, co niewyobrażalne"2. Jest to fragment szczególny, gdyż Rymkiewicz zaproponowaną tutaj tezę potwierdza jeszcze raz, pod koniec książki, tak, jakby chciał ją czytelnikowi utrwalić, aby wpisała się mocno w świadomość odbiorcy. A czytamy tam o korzyści z przekształcenia „narodowej insurekcji w narodową rewolucję" spływającą krwią zdrajców, w tym tego najważniejszego - Stanisława Augusta Poniatowskiego (chociaż szubienica nie "tworzy” krwi), którego śmierć „,byłaby wielkim wydarzeniem w historii Polski, wydarzeniem, które w swej ohydzie, potworności i wielkości radykalnie, już na zawsze zmieniłoby nasze dzieje - zupełnie inny ich obraz mielibyśmy teraz w naszych głowach"3. Przez ten straszny, ale zarazem fascynujący akt królobójstwa stalibyśmy się, jak chce Rymkiewicz, innym narodem - narodem nowoczesnym „idącym przez krew ku swoim nowym przeznaczeniom”. „Wieszający” tłum-reprezentant narodu ostrzegałby przed nieszanowaniem Polaków. Istotny jest tutaj „narodowy” wymiar tłumu jako nośnika określonych wartości. Jego siła tkwi w irracjonalności. Dzięki działaniu tłumu król mógłby przyłączyć się do panteonu wielkich. Stałby się przez to bardziej „wyrazistym" władcą, a nawet bohaterem nowego Chrztu Polski ${ }^{5}$. Byłby to wcześniej przeze mnie wspominany „akt założycielski”. Wydaje się, że działanie tłumu niczego nie buduje, gdyż jego moc, jak pisze w swym klasycznym dziele G. Le Bon, ,jest tylko niszcząca"; jednak tak naprawdę skutki jego działań mogą okazać się początkiem nowej rzeczywistości politycznej, społecznej, ekonomicznej, etc.

Ale rodzi się pytanie: co rozumieć przez pojęcie „narodu nowoczesnego"? Czy stalibyśmy się narodem historycznym w sensie politycznoprawnym? Takim już byliśmy, a sposób jego tworzenia budzi wątpliwości, gdyż, jak podkreślają niektórzy badacze, warunkami sprzyjającymi tworzeniu się nowoczesnego narodu są w sferze politycznej procesy demokratyzacyjne, na poziomie ekonomicznym - kwestie związane z modernizacją gospodarczą, a na poziomie mentalnym - świadomy i ukierunkowany wysiłek budowania wspólnoty przy mocnym współudziale elit ${ }^{7}$. Synteza idei republikańskich i kapitalistycznych nie miałaby znaczenia dla ukonstytuowania się politycznie interpretowanego narodu bez takich wartości, jak: umiejętność

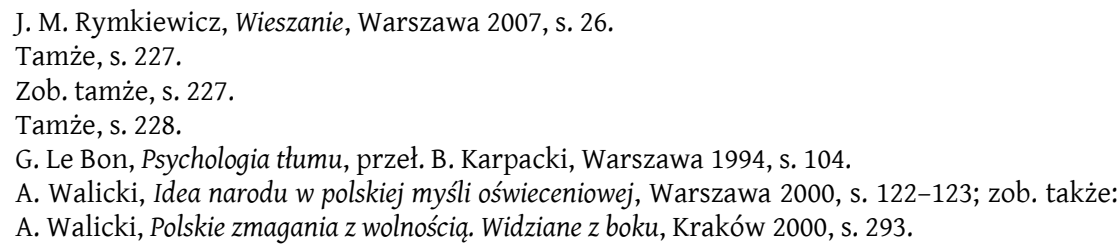


kompromisu, szacunku dla mniejszości, a także poczucia wspólnotowego ce$l^{8}$. Nie ma tutaj zbyt wiele miejsca dla krwawych rewolucji. Pomijam już fakt samego sporu o pojęcie „narodu”.

Jak pisze Andrzej Walicki, pomimo iż początki polskiej państwowości przyjmowały za kryterium polskości formułę etniczno-językową, to dzięki unii polsko-litewskiej, rozwojowi demokracji szlacheckiej i obrony zdobytych praw obywatelskich doszło do ukierunkowania rozumienia narodu jako politycznego. Warto zaznaczyć, że zainteresowanie takim rozumieniem narodu polskiego miało miejsce $\mathrm{w}$ czasach oświeceniowych i $\mathrm{z}$ ideami tego okresu (m.in. republikańskimi) były mocno związane', chociażby poprzez europejskie procesy demokratyczne ${ }^{10}$. Tworzenie politycznego narodu zostało zapoczątkowane przez postrzeganie go w kategoriach autonomicznej wspólnoty obywatelskiej w jej zewnętrznej i wewnętrznej aktywności, i nie miało swego początku w popularnej koncepcji etnicznego przebudzenia. Dowodziło to i wynikało $\mathrm{z}$ trwałego zakorzenienia w świadomości polskiej szlachty przysługujących im praw politycznych ${ }^{11}$. „Naród” uznawano za kolektywnego suwerena ${ }^{12}$.

Ale Rymkiewicz chce czegoś innego. W myśl słynnego renanowskiego dictum, że „naród to codzienny plebiscyt”, pisarz zadaje nam pytanie: czy powiesiłbyś króla? A precyzyjniej: czy poszedłbyś z tłumem powiesić króla i dalej: na ile się z tamtym tłumem utożsamiasz? Plebiscyt trwałby nadal, odtwarzany codziennie w historii i poprzez historię, w szkołach, na ulicach, w sumieniach. Dzięki temu stworzylibyśmy „piękną”, metafizyczną więź z tłumem wieszającym króla, która stałaby się trwałym elementem naszej narodowej tożsamości. Kto byłby następny? Komuniści, a nade wszystko generał Jaruzelski? ${ }^{13}$ Ale czy stałoby się tak rzeczywiście? Czy Rumuni, pomijam tutaj złożoność i niemożliwość prostej przekładalności sytuacji polskiej i rumuńskiej, są nowoczesnym narodem po straceniu Nicolaue Ceauşescu?

Tenże, Polskie zmagania..., s. 314.

Jak pisze Walicki: „Koncepcja narodu wypracowana przez polskich reformatorów epoki oświecenia, była więc par excellence polityczna (i w tym sensie zachodnia), zasadniczo różna od ideologii przebudzenia etnicznego, charakteryzującej procesy narodotwórcze w tzw. narodowościach niehistorycznych, nie posiadających własnej państwowości, języka literackiego i ukształtowanej wyższej kultury", A. Walicki, Idea narodu..., s. 10, s. 16, s. 21-22.

10 Tenże, Polskie zmagania..., s 292.

11 Zob.: Andrzej Walicki, Idea narodu..., s. 43; tenże, Polskie zmagania..., s. 292.

12 Zob. tamże, s. 68.

13 W 2004 r. w piśmie „Arcana” został zamieszczony wywiad z Jarosławem Markiem Rymkiewiczem, w którym stwierdza, że „aktem założycielskim wolnego państwa polskiego w roku 1989 powinno być wieszanie na Krakowskim Przedmieściu w Warszawie, przed Świętą Anną i przed Pałacem Staszica - właśnie to się naszym wrogom należało". 0 wieszaniu $i$ Polsce nie dla Polaków - rozmowa z Jarosławem Markiem Rymkiewiczem, „Arcana” 2004, s. 7. 
Można się zapytać, dlaczego jest to tak istotne dla naszej tożsamości narodowej? Otóż byłoby to coś, co wpisałoby się w zakres jednego z kodów tworzących narodową tożsamość. Byłby to nasz narodowy „kod transcendencji”, jako punkt odniesienia oparty na naszym stosunku do określonego sacrum ${ }^{14}$, którym to sacrum stałoby się zbiorowe „wieszanie”. Od tego momentu w naszej narodowej historii tkwiłaby immanentnie potrzeba indywidualnego katharsis w obliczu tamtego aktu „wieszania”.

Poprzez tłum, sprawcą tego dramatycznego aktu stałby się naród polski. Wpisałoby się to w naszą narodową historiozofię, gdzie romantyczny misjonizm, to splata się, to rozdziela z jej motorem: wizją samopoświęcenia, a nie "masakry” innych. W takiej historiozofii (sens dziejów) „wartośc”” wieszania jest niebagatelna - nicowałaby naszą narodową świadomość. Ale w ten oto sposób Rymkiewicz chce nam powiedzieć, że w momencie wieszania, poprzez ten akt, który byłby wyrazem wolności, istotą człowieczeństwa, Polacy dokonaliby mentalnego skoku „[...] w małych miasteczkach - pisze Rymkiewicz - wieszanie zwykle się nie udaje - żeby skutecznie wieszać, przynajmniej z powodów politycznych lub narodowych (inaczej jest w wypadku powodów ściśle osobistych), potrzebny jest wielki, najlepiej wielotysięczny tłum, taki, który potrafi zapomnieć, że składa się z poszczególnych osób, że jest właśnie - tłumem. Rzecz bowiem w tym, że wieszają nie tylko ci, którzy wieszają - to znaczy ci, którzy znaleźli się tuż przy szubienicy. Wieszają wszyscy, właśnie cały niepodzielny tłum: ci, którzy wieszają, i ci, którzy na to patrzą, i nawet ci, którzy nie chcą patrzeć, ale są obecni. Wieszający tłum staje się jednym człowiekiem, który wiesza. (...) Wieszający tłum jest jednym człowiekiem (wieszają wszystkie ręce, które tam są) a wieszanie jest głęboko, najgłębiej ludzkie. Można nawet powiedzieć, że jest rdzennie ludzkie - ludzkie ze swej istoty"15. I to nas, według Rymkiewicza, różni od zwie-

14 O formule kodów tworzących tożsamość piszą Eisenstadt i Giesen, którzy obok wspomnianego kodu transcendencji, wyrażającego się w stosunku np. do Boga, Rozumu, Postępu, Racjonalności, Rewolucji itp., wskazują jeszcze na kod pierwotności (pokrewieństwo, pokolenie, wspólnota biologiczna) i kod ogłady lub cywilizowania (czyli zasady działania, normy poruszania się w określonych sytuacjach), który jest także „dostępny” dla „obcych”. Zob. Z. Bukszański, Tożsamości zbiorowe, Warszawa 2005, s. 125-127.

15 Tamże, s. 36-37. Jak napisał G. Le Bon: „W tłumie zanika świadomość własnej odrębności, uczucia i myśli wszystkich jednostek mają jeden tylko kierunek. Powstaje jakby zbiorowa dusza”. s. 18. Jak dalej pisze Le Bon, cechą tłumu jest zanik własnego „ja”, poszczególnych jednostek, aż do stopienia się organiczną całość. „Dusza zbiorowa” jest siłą homogenizujacą: różnice intelektualne i osobowe zanikają. G. Le Bon, dz. cyt., s. 18, s. 20-21. Le Bon zwraca jeszcze uwagę na kilka istotnych elementów związanych z tłumem i jego działaniami, które w kontekście niniejszej pracy i tego, co pisze Rymkiewicz wydają się istotne dla lepszego zrozumienia przyznania tłumowi roli sprawczej w wybranym momencie historii. Jak pisze Le Bon, tłum tworzy poczucie bezkarności (s. 35); tłum oprócz czynów niegodziwych (mordy, okrucieństwo) jest jednocześnie zdolny do czynów „wzniosłych 
rząt i roślin. „Wieszanie jest (dotyczy to także gilotynowania, zresztą wszystkich technicznych sposobów mordowania) głęboko humanistyczne i wyłącznie humanistyczne - jest, w zwierzęcym i roślinnym wszechświecie, czymś zupełnie wyjątkowym. Można nawet powiedzieć, że jest jakimś humanistycznym cudem, jednym z takich cudów"16. Ta moralna i antropologiczna konstatacja nie stanowi, jak dalej wykażę, tylko wymysłu autora Wieszania, ale także chociażby J. P. Sartre'a.

Dla podkreślenia wagi naszego „narodowego wieszania” Rymkiewicz stosuje bardzo ciekawe zabiegi. Jego opisy są bardzo sugestywne, cechują się wielką dbałością o detale. „Sytuacja ulegała poprawie dopiero wczesnym latem, kiedy zmieszany z błotem gnój wysychał i dzięki temu można się go było pozbyć. Budowano wtedy z niego wieże (podobno sięgały one do wysokości pierwszego a nawet drugiego piętra), a potem wieże te podpalano - i coś w rodzaju potężnych pochodni z gnoju oświetlało w nocy Warszawę". Niestety, po jakimś czasie, a szczególnie w momencie „wieszania”, jak pisze Rymkiewicz, tych wież nie było. Jakaż więc strata? Otóż byłyby one niczym reflektory na stadionie lub wielkim koncercie rockowym. Byłoby to przedstawienie z gatunku upiornego spektaklu „światło i szubienica”. „[...] i trochę mi ich, właśnie w tym czasie brakuje - czytamy w Wieszaniu - kilkupiętrowe wieże z gnoju płonące w maju i w czerwcu przed kościołem Dominikanów Obserwantów na Nowym Świecie i przed Pałacem Brühla na Wierzbowej, i oświetlające ustawione tam szubienice oraz wisielców, kołyszących się na postronkach, to byłby wspaniały widok, to byłby jeden z najwspanialszych i najdzikszych pejzaży naszej polskiej historii”"17. Rymkiewiczowi nie starcza już męstwo i honor polskich wojsk, tu chodzi o akt radykalny obliczony na spotęgowanie obaw wrogów i zdolności narodu do czynów barbarzyńskich. Przy czym szubienic nie miało być kilka czy kilkanaście, lecz setki, a z technicznego punktu widzenia, z powodu ograniczonej „zdolności” tychże w stosunku do potrzeb, miały być sprowadzone gilotyny. Mamy więc „szał mordowania" jako coś pozytywnego ${ }^{18}$.

Rymkiewicz stosuje także swoistą historyczną kalkę. Otóż dla podkreślenia pewnego dramatyzmu, ale i uzmysłowienia czytelnikowi wagi narodowego „wieszania”, konkretne wydarzenia z 1794 roku nanosi na współcze-

i wspaniałych" (s. 39); największe szanse powodzenia maja proste hasła (np. zabić króla) (s. 43); tłum kieruje się uczuciami, nie rozumem, nie logiką (s. 72); jednostki uczestniczące w czynach tłumu, są przeświadczone o wadze działania i o spełnianiu obowiązku (s. 102). Zob.

G. Le Bon, dz. cyt.

J. M. Rymkiewicz, dz. cyt., s. 37.

Tamże, s. 14.

Zob. tamże, s. 43. 
sny układ urbanistyczny Warszawy. Oto przykład: „Sztaba uderzyła w kark, przecięła, może przepaliła szyję, głowa Fiodora Gagarina odpadła od ciała i poleciała na jezdnię, jeździec bez głowy zachwiał się w siodle, ale ściągnął cugle i utrzymał równowagę, a jego głowa odpadła w tym miejscu, gdzie teraz, vis-à-vis kościoła Panien Wizytek, u wylotu Królewskiej, stoją na czerwonych światłach samochody, jadące od strony hotelu Victoria i zmierzające skręcić na prawo w Krakowskie Przedmieście - i potoczyła się pod koła samochodów"19. A oto jeszcze jeden bardzo sugestywny, wręcz filmowy fragment: „Ścięcie prezydenta Lichockiego przy pomocy postawionej na sztorc kosy - prezydent klęczy, składając ręce do modlitwy, przed kościołem Mariackim, a potem kat, oparty na kosie (krew ścieka po ostrzu, a kat jest w krakowskiej sukmanie), podnosi za włosy jego głowę i pokazuje ją ludowi to byłaby wielka scena, o której później opowiadałyby pokolenia. Krakowianie mogliby być dumni - że mają jeszcze i taką piękną pamiątkę" ${ }^{20}$. Ale czy sam o takim widoku marzy? „Ujmując to trochę inaczej, przez czterdzieści pięć lat miałem tę szubienicę niemal pod nosem, a w każdym razie tuż przed oczyma - stała po drugiej stronie ulicy i kiedy, pracując w czytelni, podnosiłem głowę znad książki albo zostawiałem rewers w kantorku Biblioteki, musiałem na nią spojrzeć. Panie bibliotekarki, które siedzą w kantorku (od lat usytuowanym tak, że kto w nim siedzi, ma przed oczyma drugą stronę Nowego Światu), widzą tę szubienicę każdego dnia o każdej godzinie" ${ }^{21}$. Widzą, jeśli przeczytały książkę Wieszanie.

Rymkiewicz, proponuje nam także swoistą historiozofię i wskazuje na paradoksalność naszej historii, jej irracjonalny, „metafizyczny” wymiar, gdzie motorem, albo raczej „ziarnem piasku”, który ten motor powstrzymuje, bywa podagra. „16 kwietnia w trójkącie między kościołem Świętej Anny, królewskim Zamkiem i Placem Kałuskich na ulicy Miodowej miał miejsce metafizyczny skandal. Żeby artretyczny ból w czyimś wielkim paluchu, prawym albo lewym, decydował o tym, ze ktoś inny będzie wisiał lub nie, to jest z jakiegoś transcendentnego punktu widzenia - kompletnie nonsensowne i niedopuszczalne. Można z tego wyciągnąć wniosek, że z takiego punktu widzenia (który zresztą jest dla nas niedostępny i niewyobrażalny) nonsensowna i niedopuszczalna jest również cała nasza historia - jeśli decyzje o tym co się w niej wydarza, o czyim życiu oraz czyjejś śmierci, ma prawo podejmować jakiś owrzodzony oraz obolały paluch"22. Bywa, że o historii decyduje miłość, ale obolały paluch? Cóż, byłaby to historia „paluchem pisana”. Trud-

Tamże, s. 12 .

Tamże, s. 38.

Tamże, s. 65.

Tamże, s. 33. 
no powiedzieć, czy przez to byłaby gorsza czy lepsza - zapewne byłaby bardziej tajemnicza.

Wydaje się, że nie da się uciec od przemocy. Jej wątpliwym „fenomenem" zajmują się wszelkie dziedziny nauki: psychologia, prawo, socjologia, historia, medycyna, i oczywiście filozofia. A co ze sferą polityki? Tutaj nie jest inaczej, skoro, jak piszą m.in. P. Berger: „Przemoc jest ostateczną podstawą wszelkiego porządku politycznego”23; czy C. Wright Mills: „Istota wszelkiej polityki sprowadza się do walki o władzę, ostateczną zaś formą władzy jest przemoc"24. Zasadne jednak staje się pytanie o sens przemocy.

Ci, którzy badają różne przejawy przemocy, podkreślają jej etymologiczne pochodzenie. Nie zawsze była ona rozumiana tak jak współcześnie. Jak podkreśla B. Skarga, dawniej w języku staropolskim, to pojęcie nie miało tak wyraźnego, negatywnego zabarwienia i oznaczało "spotęgowanie mocy”, a zwrot nastąpił na przełomie XVIII i XIX wieku, na fali wydarzeń rewolucyjnych ${ }^{25}$. Etymologicznie wywodzi się od takich słów jak: siła przemagająca, przemożenie, wielka moc, przemożność ${ }^{26}$. Tak więc, przemoc oznaczała w pewnym sensie potęgę, znaczne możliwości, a nie gwałt, przymus, okrucieństwo. H. Arendt słusznie zauważa pewną niedoskonałość semantyczną, jaką jest obarczona dyskusja w kręgu teorii polityki, objawiającą się częstym błędnym zamiennym stosowaniem słów: władza, moc, siła, autorytet i przemoc. I dodajmy jeszcze inny znaczący błąd, czyli utożsamianie przemocy z przymusem. Według Arendt, władza to ludzka zdolność jednomyślnego działania; moc, to „coś w jednostce, w tym, co istnieje jako indywiduum; jest wartością zawartą w przedmiocie lub osobie należącą do ich charakteru"; siła, powinna „wskazywać na energię wyzwalaną w wyniku ruchów fizycznych lub społecznych"; autorytet, występuje wówczas, gdy następuje bezwzględne uznanie, bez stosowania przymusu czy przemocy; przemoc - jak pisze Arendt - „fenomenologicznie bliska jest mocy, ponieważ środki przemocy, podobnie jak wszystkie inne narzędzia, są przeznaczone i wykorzystywane do zwiększenia naturalnej mocy zanim, w ostatnim stadium swego rozwoju,

\footnotetext{
P. Berger, Zaproszenie do socjologii, przeł. J. Skawiński, Warszawa 2000, s. 71.

C. Wright Mills, Elita władzy, Warszawa 1961, s. 228.

Zob. B. Skarga, O przemocy, „Gazeta Wyborcza” 2003, s. 23.

Por. M. S. B. Linde, Słownik języka polskiego, t. 4, Poznań 1951, Warto pamiętać o pewnym pomieszaniu pojęciowym, czasami świadomym a czasami nie, które dotyczy także przemocy. Zwraca na to uwagę G. Sartori, określając ja mianem „gry w słowa”, a „która bardzo skutecznie zniszczyła wszelkie stałe intersubiektywne relacje między sformułowaniami i pojęciami. [...] Podobnemu zniekształceniu uległa «przemoc» kiedy zaczęto mówić o «strukturalnej przemocy» (czyli przemocy bez przemocy)" Pojęcie przemocy ulega zniekształceniu, gdy wszelkie ograniczenia nazywamy przemocą. Zob. G. Sartori, Teoria demokracji, przeł. P. Amsterdamski i D. Grinberg,, Warszawa 1998, s. 106, 114 .
} 
jej nie zastąpią" ${ }^{27}$. Dlatego przemoc „zawsze potrzebuje narzędzi”28. Arendt powraca do etymologicznego rozumienia przemocy jako spotegowania, w tym przypadku, przy pomocy instrumentów, naturalnej mocy, indywidualnej, grupowej czy państwowej. Od mocy już nieduży krok do przemocy, krok wynikający z ludzkiej natury, z samego faktu egzystencji („Jest więc związana z samym istnieniem człowieka”), z ludzkich potrzeb („Każdy z nas pragnie coraz to większej mocy. [...] Przemoc rodzi się w nas, z naszej woli panowania, z naszych ambicji, pragnień zdobycia coraz to nowych przestrzeni działania i myślenia, które nieraz wymagają pokonania przeciwności"), dlatego posiłkuje się narzędziami ${ }^{29}$. Jest to najgorsze z możliwych rozwiązań.

Gdy wkraczamy na pole rozważań o przemocy, może zaskoczyć nas szerokie spektrum jej oceny. Choć większość badaczy podkreśla zdecydowanie jej negatywną stronę, to daje się zauważyć podejście relatywistyczne, a nawet będące usprawiedliwieniem przemocy czy też czasami jej apologią. W tym momencie, rodzi się zasadnicze pytanie: czy można usprawiedliwić przemoc, odwołując się do perspektywy przyszłego jej wyeliminowania? Czy w imię jakiś idei, nawet walki z przemocą, można ją stosować? Radykalizując takie obawy, słusznie pyta B. Skarga: czy „w imię walki z przemocą [unicestwilibyśmy - I. K.] całą naszą cywilizację, wraz z tym wszystkim, co ona nam niesie, z jej urządzeniami społecznymi, tradycją wiedzy i kultury, wartościami, które są obecne zawsze gdzieś u podstaw wszelkich poczynań ludzkich?" ${ }^{30}$ Przemoc przeciwko przemocy.

Dziś przemoc jednoznacznie kojarzy się negatywnie i jest utożsamiana z takimi pojęciami, jak: agresja, gwałt, śmierć, terror, przestępstwo, itp. R. Tokarczyk w tekście Przymus a prawo, podaje kilka zasadniczych cech przemocy. Są to: brutalizacja, agresywne i destrukcyjne zachowanie, siłowa dysproporcja między zantagonizowanymi stronami. Według niego, przemoc „polega na przymuszaniu jednostki lub grupy - jako ofiary przemocy - siłą, bronią, groźbą do działania bezprawnego wbrew ich woli”" ${ }^{31}$. Co istotne, przemoc jest formą przymusu, rodzajem przymusu, różniącym się jednak znaczącym natężeniem, brutalizacją i agresją. Nie każda forma przymusu stanowi przemoc. Wymienia też rożne formy przemocy, m.in.: polityczną

27 H. Arendt, O przemocy, w: taż, O przemocy. Nieposłuszeństwo obywatelskie, przeł. A. Łagodzka, W. Madej, Warszawa 1999, s. 56-59.

Tamże, s. 8.

Zob. B. Skarga, dz. cyt., s.23.

Tamże, s. 24.

31 R. Tokarczyk, Przymus a prawo, w: Przemoc i filozofia, red. M. Kociuba, J. Mizińska, Lublin 2004, s. 27. 
(„zmierza do realizacji celów politycznych - przywódców, partii, organizacji, rządu - środki przymusu bezprawnego [...]) i społeczną; rewolucyjną (występującą przeciwko jakiemuś status quo, przybierającą często formy gwałtowne i nacechowane okrucieństwem, posługującą się przemocą fizyczną i psychiczną, a także innymi sposobami przemocy, np. państwową, polityczną) i nierewolucyjną; sprawiedliwą (związaną z koncepcjami wojen, rewolucji, buntów sprawiedliwych) i niesprawiedliwą; państwową (gdy przymus wykracza poza granice ustanowione prawem) i antypaństwową (pod postacią rewolucji, buntów, terroryzmu, itp.); stabilizującą i destabilizującą; wewnętrzną i zewnętrzną; fizyczną i psychiczną; bezpośrednią i pośrednią; indywidualną i grupową, itp. ${ }^{32}$

Z kolei B. Skarga w cytowanym wcześniej eseju przywołuje podział i definicje przemocy, których dokonał E. Dembowski. „Przemoc - pisze Dembowski - kilkakrotna jest. I tak: Przemoc fizyczna; przemoc ta jest stosunkiem mocniejszego do słabszego. Przemoc własności po wtóre, przemoc bogatego nad ubogim, która w ogólności da się odkreślić wyrazem zależność, tak jak przemoc fizyczna może się odkreślić wyrazem niewola. Na koniec przemoc umysłowa, przemoc mądrzejszego nad mniej oświeconym, przemoc bystrzejszego umysłem nad niedołężnym, dająca się w swym skutku określić wyrazem wpływ stanowczy"33. Dalej, następuje rozwinięcie tych trzech rodzajów przemocy. Istotna jest jednak konkluzja B. Skargi, w odniesieniu do koncepcji Dembowskiego, że „wystarczy znieść własność prywatną, aby przemoc wyeliminować". Lecz były to tylko nadzieje, które z naszej perspektywy, po historycznych wydarzeniach, po usiłowaniu jej urzeczywistnienia, nie nadają się do obrony ${ }^{34}$.

Próby zrozumienia przemocy, a przede wszystkim jej zminimalizowania, wychodziły z założenia, że należy poznać jej źródło. Wskazuje się na różne źródła przemocy, m.in.: ludzką naturę, socjalizację, życie społeczne, prawa, religię, własność, państwo, mass media ${ }^{35}$.

Wydaje się, że próby periodyzacji dziejów i cywilizacyjne wartościowanie także biorą pod uwagę stosunek do przemocy. H. Arendt, analizując dwie sfery życia starożytnych Greków, wskazuje na samorealizację politycz-

32 Zob.: tamże, s. 27-28. B. Skarga, w cytowanym eseju także zwraca uwagę na dość częsty błąd utożsamiania przymusu z przemocą; B. Skarga, dz. cyt., 24.

33 B. Skarga, dz. cyt; E. Dembowski, Twórczość w żywocie społeczności, w: tenże, Pisma wybrane, t. 3, Warszawa 1955, s. 235-238.

34 Zob. B. Skarga, dz. cyt., s. 23.

35 Zob. R. Tokarczyk, dz. cyt., s. 30-32. Nawet tak szacowne dzieło jak Stary Testament, jest relatywnie przesiąknięte przemocą i znajduje się tam 76 aktów przemocy „(51 zabójstw, 4 powieszenia, jeden akt kanibalizmu (!), 6 pobić i uderzeń, 8 uwięzień, dwa akty znęcania się, 4 gwałty)". Zob. tamże, s. 31. 
ną i publiczną poprzez mowę i działanie, o ile obie nie stosują przemocy, która ,jest niema i z tego powodu nie może być wielka"36. Przemoc nie może być wartością dla tak rozumianej sfery publicznej. „Być istotą polityczną,- pisze Arendt - żyć w polis, znaczyło, że o wszystkim decydowały słowa i perswazja, a nie siła i przemoc. Dla Greków zmuszanie poprzez przemoc, rozkazywanie w miejsce perswazji, to przedpolityczne sposoby postępowania charakterystyczne dla życia poza polis [...]"37. Polis wyznaczała nie tylko standardy formalne, ale i wartości.

Wróćmy w tym momencie do teorii A. Kojève'a. Biorąc się do komentowania czwartego rozdziału heglowskiej Fenomenologii ducha, Kojève zrobił to w sposób ukazujący historię jako ciągły dialektyczny spór Pana i Niewolnika. Spór, dodajmy, nacechowany wszelkimi negatywnymi cechami: okrucieństwem, przemocą, podstępem, walką, itp. „Historia - pisze Kojève - jest historią krwawych walk o uznanie (wojny, rewolucje) i prac, które przeobrażają Przyrodę" ${ }^{38}$. Dwie zasady, wyznaczają stan człowieka naturalnego: pożądanie i działanie. Człowieczeństwo jest konstytuowane przez narażanie życia w imię Pożądania. „Człowiek - pisze autor Wstępu - «okazuje się» ludzki, narażając swe życie w celu zaspokojenia ludzkiego Pożądania, tzn. swego Pożądania, które kieruje się na inne Pożądanie. Otóż pożądając Pożądania, to

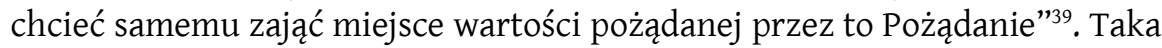
permanentna walka, która nie zawsze jest jawną fizyczną przemocą, trwa aż do Końca Historii. Takie rozwiązanie jest jednym z dwóch sposobów walki, „dialektycznym” („cywilizowanym”), który „«znosi» Wroga, zachowując go i «sublimując»”, w przeciwieństwie do walki „pogańskiej”, której celem jest ostateczne unicestwienie Wroga ${ }^{40}$. W naszym narodowym wieszaniu tłum też pożądał - władzy nad życiem.

Ogromna jest też pokusa usprawiedliwiania przemocy w imię wyższych celów. Racjonalizm instrumentalnego wykorzystania przemocy, jaki przedstawiali np. komuniści, miał być wykorzystany do usprawnienia nowej dyktatury - dyktatury proletariatu, której zadaniem miało być urzeczywistnienie utopii komunistycznej. Jednak nie każde takie wykorzystanie przemocy da się „racjonalnie” wytłumaczyć. „W tym przypadku bowiem - pisze

\footnotetext{
H. Arendt, Kondycja ludzka, przeł. A. Łagocka, Warszawa 2000, s. 31.

Tamże, s. 32.

A. Kojève, Wstęp do wykładów o Heglu, przeł. Ś. F. Nowicki, Warszawa 1999, s. 87.

Tamże, s. 12.

40 Zob. tamże, s. 284. Ponadto, Kojève pisze: „Jako skończoność, czyli czasowość, oraz negatywność, czyli wolność, śmierć jest w podwójnym sensie ostateczną podstawą i pierwszą siłą poruszającą Historii. I właśnie dlatego proces historyczny wymaga z konieczności tego, by śmierć stawała się aktualną, bezpośrednią rzeczywistością za sprawą wojen i krwawych rewolucji”(tamże, s. 580).
} 
C. Schmidt, autor Teologii politycznej - w grę wchodzą nowe, irracjonalne motywy stosowania przemocy. Irracjonalizm nie jest już żadną fantastyczną utopią, która swoje źródła czerpie ze skrajnie przesadnej, radykalnej opozycji do racjonalizmu, ale oznacza nowe podejście do racjonalnego myślenia, wiarę $\mathrm{w}$ instynkt i intuicję, która z kolei odrzuca wszelką ideę dyskusji, a w każdym razie nie zakłada, że celem dyktatury jest wychowanie ludzi zdolnych do prowadzenia dojrzałej debaty"41. Racjonalność została sprowadzona do usprawiedliwienia przemocy. Przemoc zawsze oznacza wykluczenie dialogu, jest na tyle toksyczna, że w przyszłości ten staje się trudny i przesiąknięty nieufnością. Komunikacja w sytuacji naznaczonej pamięcią przemocy nie jest prosta i nie zawsze prowadzi do pokojowej egzystencji ${ }^{42}$. W takim wypadku, stajemy wobec problemu przyznania przemocy pozytywnych elementów, w które wielu nie wątpiło.

H. Arendt, w swej analizie roli przemocy w historii, zwraca uwagę, że teoretyczne opracowania na temat gloryfikacji przemocy jako takiej, przemocy „czystej”, pojawiły się dopiero w czasach nowożytnych, w dobie rewolucji. Wcześniej, „[...] element przemocy miał charakter ściśle instrumentalny, był środkiem, wymagającym celu, który go usprawiedliwia i wyznacza $\mathrm{mu}$ granice" ${ }^{43}$. Było to wynikiem wiary w kontemplację i działanie racjonalne. Zmiana nastąpiła wówczas, gdy człowiek uwierzył, w ukonstytuowanie (zdefiniowanie) siebie tylko dzięki wytwarzaniu. Zamiast animal rationale stał się homo faber, co pozwoliło ludziom błędnie uwierzyć, że „«robią» historię tak jak przyrodę «zrobił» Bóg”. Takie podejście do egzystencji ludzkiej, uaktywniło ukryte dotąd pokłady przemocy. „Szczególnie uderzające - pisze Arendt - było to w serii rewolucji charakterystycznych dla epoki nowożytnej, które - poza amerykańską wojną o niepodległość - ukazują to samo połączenie dawnego rzymskiego entuzjazmu do zakładania nowego państwa z gloryfikacją przemocy jako jedynego środka do jego «utworzenia»" ${ }^{44}$. Dla-

${ }^{41}$ C. Schmitt, Duchowa i historyczna sytuacja dzisiejszego parlamentaryzmu, w: C. Schmitt, Teologia polityczna i inne pisma, przel. M. A. Cichocki, Kraków 2000, s. 179.

42 Zob. A. Giddens pisze: „Między komunikowaniem się a przemocą występuje zatem ostrzejsze napięcie niż to, które powstało we wcześniejszych fazach rozwoju społeczeństw nowoczesnych - nowoczesnych odnosi się to nie tylko do społeczeństw uprzemysłowionych, ale także do skali globalnej. W takiej sytuacji, czy to w połączeniu z bardziej klasycznymi instytucjami demokratycznymi czy nie, demokracja dialogowa staje się głównym środkiem zapanowania nad przemocą". Zob. A. Giddens, Poza lewica i prawica. Przyszłość polityki radykalnej, przeł. J. Sekwański, Poznań 2001, s. 267. Mamy w pamięci nie tak odlegle dramatyczne wydarzenia w Jugosławii czy Ruandzie, i do dziś w umysłach tych ludzi pozostała trucizna, która eliminuje i blokuje dialog między zwaśnionymi stronami, które wyrządziły sobie tyle zła.

43 H. Arendt, Kondycja ludzka, s. 249.

44 Tamże. 
tego też, taką popularność uzyskało słynne dictum: „przemoc jest akuszerką każdego starego społeczeństwa brzemiennego nowym" ${ }^{45}$. W ten sposób przemoc staje się jakby nie tylko niezbędnym elementem wszelkich zmian w polityce, ale także czynnikiem, od którego zależy „jakość” nowej rzeczywistości. Jak pisze F. Engels, przemoc ,jest narzędziem, za pomocą którego ruch społeczny przebija sobie drogę rozsadzając skostniałe, obumarłe formy polityczne, [...]"46. Nie ma wątpliwości, że najlepszym sposobem tworzenia nowej rzeczywistości, a tym samym redefinicji działania politycznego i społecznego, jest rewolucja, która z konieczności musi być krwawa i gwałtowna. „Rewolucja - pisze Lenin - jest aktem, przez który jedna część ludności narzuca swą wolę drugiej części za pomocą strzelb, bagnetów i armat, [...]" ${ }^{\prime 4}$. Dlatego H. Arendt odmawiała wielkości rewolucji francuskiej, gdyż widziała w niej źródło późniejszych gwałtów, okrucieństwa aciene regime i jakobińskiego terroru. Wskazała natomiast na bardzo istotny problem: narodzin „biernego oporu”. W krwawej rewolucji jest jeszcze jeden istotny czynnik, który deprecjonuje jej owoce. Jak zauważa J-M. Muller, historia rewolucji pokazuje, że stosowana przez nie w imię ideałów przemoc, w końcu je zaprzepaszcza, czy wręcz tym ideałom przeczy, tak jak to miało miejsce w Rewolucji Francuskiej, a przynajmniej w jej początkowym okresie $e^{48}$.

Bunt przeciwko złu bywa usprawiedliwiony wówczas, gdy przemoc nie przekroczy granicy krytycznej i nie stanie się celem samym w sobie. Moralne pytanie: czy cel uświęca środki, które powraca niczym leitmotiv, jest szczególnie aktualne przy walce o wyższe cele, np. niepodległość. Przywołajmy pewien znany przykład nawoływania do przemocy w walce o suwerenność kraju.

J. P. Sartre należy do tych filozofów, którzy, gdy zajmowali się polityką, popełniali wiele istotnych błędów. Jednym z nich jest stosunek do prze-

45 K. Marks, Kapitat, t. 1, s. 810; cyt. za H. Arendt, Kondycja ludzka, s. 249.

46 F. Engels, Anty-Dühring: pan Eugeniusz Dühring dokonuje przewrotu w nauce, przeł. P. Hoffman, Warszawa 1948, s. 205.

${ }^{47}$ W. I. Lenin, Państwo a rewolucja, w: F. Engels, W. I. Lenin, K. Marks, 0 anarchizmie i anarchosyndykalizmie. Wybór, Warszawa 1984, s. 385. (Zob. W. I. Lenin, Dzieła, t. 25, Warszawa 1951, s. 450).

48 Zob. J-M. Muller pisze także, że przemoc znajduje w ideach, doktrynach tradycji, poczesne miejsce. „Objawia się ona w tak głębokim związku z licznymi cnotami, takimi jak: odwaga, śmiałość, męstwo, honor, szlachetność, żarliwe umiłowanie sprawiedliwości i wolności, że sama wydaje się cnotą. Proponowany nam do podziwiania bohater - czy to historyczny czy to legendarny, zawsze w jakiś sposób posługuje się przemocą". J-M. Muller, Strategia politycznego działania bez stosowania przemocy, Warszawa 1984, s. 8. 
mocy $^{49}$. W Posłowiu do znanej książki F. Fanona Wyklęty lud ziemi, Sartre przekonuje, że można pozytywnie odkryć człowieczeństwo w akcie przemocy. „Czy wyzdrowienie jest możliwe?” - pyta retorycznie. „Tak. Przemoc, jak włócznia Achillesa, ma moc uzdrawiania ran, które zadała" ${ }^{50}$. Pomimo naszej niechęci do przemocy, jest ona formą katharsis, balsamem na zadane przez ciemiężycieli rany. Parafrazując słowa Hegla - przemoc zostaje zniesiona przez przemoc ${ }^{51}$. Fanon, który osnowę swej pracy oparł na słowach: „dekolonizacja zawsze jest zjawiskiem gwałtownym", wskazuje na potrzebę zastosowania przemocy w sytuacji, gdy celem jest wyzwolenie z kolonialnych zależności. Ludzie marginalizowani, wyłączeni ze społeczeństwa, biedni, zniewoleni, itp., odzyskają swe utracone człowieczeństwo (godność?!), poprzez zastosowanie przemocy. Fanon proponuje odwrócenie sytuacji także przy pomocy przemocy. Pisze: „[...] kolonializm nie jest mechanizmem myślącym, nie jest ciałem obdarzonym rozumem. Jest przemocą w stanie czystym i może ustąpić jedynie przed jeszcze większą przemocąa" ${ }^{2}$. W takiej sytuacji, potencja musi być sztucznie wzmocniona poprzez odpowiednie narzędzia materialne i niematerialne, zabrane jej posiadaczom. Choć słowa te brzmią radykalnie i złowrogo, to sam Fanon, na co zwraca uwage H. Arendt, przestrzegał przed zbytnią brutalizacją i okrucieństwem, gdyż może się to obrócić przeciwko nim samym ${ }^{53}$. Lecz jak zachować słuszną miarę? Sartre jakby nie dostrzega tego problemu.

Czy cel, jakim jest niepodległość, uprawomocnia rozrost przemocy? Jeśli ta rodząca się w ludziach jest, jak chce Fanon, wynikiem sytuacji skolonizowania, stanowi element pozytywny poprzez moc formowania pewnej wspólnoty w kontekście walki i odpowiedzialności, a nawet fundament przyszłego państwa, to czy takie państwo będzie praworządne ${ }^{54}$ ?

Do moralności odwoływali się nie tylko przeciwnicy przemocy, lecz także jej zwolennicy. Oto, jak wskazuje L. Kołakowski, G. Sorel w swych Refleksjach o przemocy, które według wielu są prawdziwą apologią przemocy, wskazuje, że przemoc może być „moralnie doniosła o tyle, o ile moralnie wychowuje tych, którzy ją stosują. Inaczej: chodzi o przemoc typu wojennego,

${ }^{49}$ Zob. H. Arendt, porównując słynne Refleksje o przemocy G. Sorela z koncepcjami J. P. Sartre'a pisze, że Sartre w gloryfikacji przemocy jako środka zmiany rzeczywistości posuwa się znacznie dalej niż Sorel w swych Refleksjach. Zob. H. Arendt, O przemocy, s. 19-20.

50 J. P. Sartre, Posłowie, w: F. Fanon, Wyklęty lud ziemi, przeł. H. Tygielska, Warszawa 1985, s. $225,233$.

51 Hegel napisał: „[...] przymus zostaje zniesiony przez przymus”. G. W. F. Hegel, Zasady filozofii prawa, przeł. A. Landman, Warszawa 1969, s. 103.

52 F. Fanon, dz. cyt., s. 38.

53 Por.: F. Fanon, dz. cyt., s. 100; H. Arendt, O przemocy, s. 22.

54 Zob. F. Fanon, dz. cyt., s. 61. 
nie zaś policyjnego; przemoc bez okrucieństwa i przemoc, której motywem nigdy nie jest zawiść ubogich do bogaczy - uczucie rujnujące moralnie i degradujące proletariat" ${ }^{\prime 5}$. Jest to odwołanie do wiary w twórczą moc cnót walki, działania. „Wojna i męstwo - napisał F. Nietzsche, z którego czerpał Sorel - uczyniły więcej wielkich rzeczy niż miłość bliźniego" ${ }^{56}$. To, co u Sorela zasadnicze odnosi się do usprawiedliwiającej przemoc teorii mitu. Mit jakiejś sytuacji, np. rewolucji i rzeczywistości porewolucyjnej jest formą dogmatu, którego nie można obalić, a który usprawiedliwia przemoc. Mit, ,jest tylko perspektywą ostatecznej walki. [...] jest jedynym narzędziem, które pozwala walczącej grupie zachować solidarność, heroizm, ducha poświęcenia. Jest stanem świadomości, która oczekuje i przygotowuje jednorazową, gwałtowną zagładę istniejącego świata [...] Mit jest aktem tworzenia bez przewidywania"57.

Tak jak u Fanona, w akcie przemocy możemy doszukiwać się motywu solidaryzmu i poczucia więzi, tak jest też u Rymkiewicza. Podobnie jak Kojève widział w poświęceniu życia istotę tego, co ludzkie, jak Sartre widział w przemocy akt oczyszczania i człowieczeństwa, tak też widzi to Rymkiewicz. Wbrew wielu negatywnym opiniom, m.in. o szkodliwości takiej literatury, publikacje takie jak Wieszanie są potrzebne, chociażby po to, aby wywołać dyskusję.

I R E N E U S Z K O E P K E

55 L. Kołakowski, Główne nurty marksizmu. Część II. Rozwój, Poznań 2000, s. 1999; zob. także: G. Sorel, Refleksje o przemocy, „Colloquia Communia” 1983, nr. 1.

56 F. Nietsche, To rzekł Zaratustra, przeł. S. Lisiecka, Z. Jaskuła, Warszawa 1993, s. 52.

57 Tamże, s. 193-195. 


\section{Abstract}

In year 2007 Polish poet, writer and literary critic, Jarosław M. Rymkiewicz published the book Wieszanie ("Hanging"), in which he contained his thesis concerning supposed positive value which the hanging of king August Stanisław Poniatowski in year 1794 would have for Poland's history. The title "hanging" would be of great meaning for our national identity as well as for our philosophy of history. In the article I tried to show the most important plots of Rymkiewicz's book which also served me as a basis for short considerations over phenomenon of violence as an act of change of political reality. 